\title{
Integrated Ultrasonication and Microbubble-Assisted Enzymatic Synthesis of Fructooligosaccharides from Brown Sugar
}

\author{
Worraprat Chaisuwan ${ }^{1,2}$, Apisit Manassa ${ }^{1,2}$, Yuthana Phimolsiripol 2,3(D, \\ Kittisak Jantanasakulwong ${ }^{2,3}$, Thanongsak Chaiyaso ${ }^{2,3}$, Wasu Pathom-aree ${ }^{4}$, SangGuan You 5 \\ and Phisit Seesuriyachan $2,3, *$ \\ 1 Interdisciplinary Program in Biotechnology, Graduate School, Chiang Mai University, \\ Chiang Mai 50200, Thailand; worraprat_chai@cmu.ac.th (W.C.); apisit_man@cmu.ac.th (A.M.) \\ 2 Faculty of Agro-Industry, Chiang Mai University, 155 Moo 2, Mae Hia, Mueang, Chiang Mai 50100, Thailand; \\ yuthana.p@cmu.ac.th (Y.P.); kittisak.jan@cmu.ac.th (K.J.); thanongsak.c@cmu.ac.th (T.C.) \\ 3 Cluster of Agro Bio-Circular-Green Industry (Agro BCG), Chiang Mai University, \\ Chiang Mai 50200, Thailand \\ 4 Department of Biology, Faculty of Science, Chiang Mai University, Chiang Mai 50200, Thailand; \\ wasu.p@cmu.ac.th \\ 5 Department of Marine Food Science and Technology, Gangneung-Wonju National University, Gangneung, \\ Gangwon 210-702, Korea; umyousg@gwnu.ac.kr \\ * Correspondence: phisit.seesuriyachan@gmail.com or phisit.s@cmu.ac.th; Tel.: +66-53-948201
}

Received: 5 October 2020; Accepted: 7 December 2020; Published: 10 December 2020

check for updates

\begin{abstract}
Fructooligosaccharides (FOS) are considered prebiotics and have been widely used in various food industries as additives. Ultrasonication has been widely used to enhance food processes; however, there are few reports on ultrasound-assisted FOS synthesis. In the present study, FOS were produced from brown sugar using ultrasonication combined with microbubbles, and the production was optimised using a Box-Behnken experimental design. Here we showed that a combination of ultrasonication and microbubbles could boost the enzyme activity by $366 \%$, and the reaction time was shortened by $60 \%$. The reaction time was a significant variable affecting the FOS production. The optimum conditions were $5 \mathrm{~min} 45 \mathrm{~s}$ of ultrasonication and $7 \mathrm{~min} 19 \mathrm{~s}$ of microbubbles with a reaction time of $5 \mathrm{~h} 40 \mathrm{~min}$. The maximum enzyme activity and total FOS yield were $102.51 \pm 4.69 \mathrm{U} \cdot \mathrm{mL}^{-1}$ and $494.89 \pm 19.98 \mathrm{mg} \cdot \mathrm{g}^{-1}$ substrate, respectively. In an enlarged production scale up to $5 \mathrm{~L}$, FOS yields were slightly decreased, but the reaction time was decreased to $4 \mathrm{~h}$. Hence, this technique offers a simple and useful tool for enhancing enzyme activity and reducing reaction time. We have developed a pilot technique as a convenient starting point for enhancing enzyme activity of oligosaccharide production from brown sugar.
\end{abstract}

Keywords: fructooligosaccharide; optimisation; Box-Behnken; ultrasound; microbubble; transfructosylation; enzyme activity enhancement

\section{Introduction}

Nowadays, people have attempted to improve their health and diet due to increased non-communicable diseases, including cancers, diabetes, metabolic syndrome, hypertension, stroke, and heart disease [1]. Therefore, many products, such as functional foods that have positive effects on health have been developed. Functional foods can be defined as foods that provide nutrients and energy, modulate an individual's health and physiological functions, and reduce diseases [2]. Oligosaccharides (short-chain carbohydrates) with prebiotic properties such as fructooligosaccharides 
(FOS), galactooligosaccharides (GOS), xylooligosaccharides (XOS), inulooligosaccharides (IOS), soybean oligosaccharides (SOS), and cello-oligosaccharides (COS) have been interested from researchers because they have potential as ingredients in functional foods [3,4]. Among them, FOS are well-known non-digestible carbohydrates and have been extensively used in various food products [5].

It is safe to use FOS in food products, since FOS have been recognised by the Food and Drug Administration of the United States to be generally safe (GRAS) [6,7]. In the food industry, because FOS have favourable characteristics, including low calories, sweetening property, and unique physiochemical properties, they have been used as food additives in pastry, confectionery and dairy products $[8,9]$. Furthermore, FOS have many advantages for an individuals' health due to their biological activities, including prebiotic, anticancer, and immunomodulatory properties. FOS serve as carbon and energy sources for probiotics in the large intestine. FOS can promote the growth of prebiotic strains such as Bifidobacterium spp. and Anaerostipes caccae, butyrate-producing bacterium [10,11]. In contrast, FOS can inhibit the growth of some pathogenic bacteria such as Clostridium spp. [12]. As a prebiotic effect, gut microbiota can ferment FOS and then produce short-chain fatty acids (SCFAs), such as acetate, butyrate and propionate, which modulate intestinal epithelial functions and activate the host's immunity [13]. Buddington and colleagues [14] reported that FOS-fed mice had a low number of Listeria monocytogenes and Salmonella enterica subsp. enterica serovar Typhimurium (pathogenic bacteria). Taper and Roberfroid [15] also reported that FOS exhibited anti-proliferative effects on cancer cells in mice. However, consuming high levels of FOS (>20 g/day) might cause abdominal distension, abdominal rumbling, abnormal flatulence and abdominal pain because of excess gases from bacterial metabolism in the large intestine [16].

FOS are carbohydrates consisting of fructose monomers (2-10 residues) and can be naturally found in plant sources, such as onion, barley, asparagus, garlic, banana, and Jerusalem artichoke [17,18]. Moreover, FOS can be synthesised from low-cost materials such as sucrose and longan syrup, using an enzymatic reaction of transfructosylating enzymes, also called transfructosylation [19]. Enzymes with transfructosylation activity can transfer fructosyl groups, which are significant in FOS synthesis [20]. In the enzymatic synthesis, FOS can be produced using various enzymes, including $\beta$-fructofuranosidases (EC 3.2.1.26), $\beta$-fructosyltransferases (EC 2.4.1.9), and inulinases (EC 3.2.1.7) $[8,20,21]$. The commercial enzyme Pectinex Ultra SP-L was derived from Aspergillus aculeatus and is a complex enzyme, mainly consisting of polygalacturonase (pectinase) and others (cellulase, $\beta$-galactosidase and $\beta$-fructosyltransferases). This enzyme has been widely used for FOS production from sugar because it possesses high fructosyltransferase activity and was used in the present study $[19,22]$. After FOS synthesis, FOS molecules are a mixture of 1-kestose (1-kestotriose; GF2), nystose (1,1-ketstotetraose; GF3), and $1^{\mathrm{F}}$ - $\beta$-fructofuranosylnystose (1,1,1-kestopentaose; GF4), which are categorised by the number of fructose monomers linking to glucose [8]. After production, some glucose and fructose contents remain as by-products, as well as excess sucrose, so it is necessary to purify the product. There are various techniques for purification of FOS, for example, chromatography, membrane filtration (such as nanofiltration), charcoal column and so on [23-25].

Various chemical, physical and biological approaches have been used to enhance enzyme activity for the improvement of FOS production. Among the physical methods, ultra-high pressure (UHP) is a useful technique that can activate or inactivate enzyme activity. In optimal levels of pressure, UHP enhanced fructosyltransferase activity of Pectinex Ultra SP-L and FOS contents could be increased 2.5-fold [5].

In the last few decades, an ultrasonication has been widely applied in various food and biotechnological processes. This technique has been performed as an enhancement for metabolite extraction from natural sources, such as fruits, microbial cells, and vegetables, among others, and can change the structure of food products $[26,27]$. This method has been used for enzyme inactivation; however, a large number of reports have been confirmed that the technique was able to activate some enzymes under suitable conditions [28]. Additionally, an ultrasonication has been approved that can 
increase enzyme activity at an appropriate frequency and intensity levels because ultrasound can act on conformation changes in enzymes or substrates [28,29]. Ultrasound can improve the activity of many enzymes including $\alpha$-amylase, $\beta$-D-glucosidase, cellulose, dextranase and lipase [28,30-32]. Therefore, this method has been extensively used in various food industries, especially in fruit juice production, where it slightly affects the quality of fruit juice $[33,34]$. However, there are few reports on the use of ultrasonication for FOS production. This study, therefore, aimed to investigate the effects of ultrasonication and microbubble on enhancing enzyme activity for FOS production. Moreover, optimisation of the processes was done by a Box-Behnken design, and FOS yields (mg.g ${ }^{-1}$ substrate) were quantified using high-performance liquid chromatography (HPLC).

\section{Materials and Methods}

\subsection{Enzymes and Chemicals}

Pectinex Ultra SP-L, a commercial pectinolytic and cellulolytic enzyme derived from Aspergillus aculeatus, was purchased from Novozymes (Bagsværd, Denmark). Commercial brown sugar and white sugar derived from sugar canes were used as substrates in this study. 3,5-dinitrosalicylic acid (DNS) was purchased from Sigma-Aldrich (St. Louis, MO, USA). Standard carbohydrates including 1-kestose, nystose, $1^{\mathrm{F}}$ - $\beta$-fructofuranosylnystose, sucrose, glucose and fructose were obtained from Wako Pure Chemical Industries (Osaka, Japan).

\subsection{Enzymatic Assay}

Enzyme activity was determined based on the generation of reducing sugar using sucrose as a substrate [19]. A concentration of Pectinex Ultra SP-L used in this study was $100 \mathrm{U} \cdot \mathrm{mL}^{-1}$, which was reported in a previous study [5]. Briefly, sucrose was dissolved in a sodium acetate buffer (pH 6.5) at a final concentration of $2 \%(w / v)$. Next, $0.2 \mathrm{~mL}$ of Pectinex Ultra SP-L and $1.8 \mathrm{~mL}$ of sucrose solution were mixed and then incubated at $55^{\circ} \mathrm{C}$ for $15 \mathrm{~min}$. Reducing sugars released from sucrose were analysed using the DNS assay [35]. After incubation, the sample $(1 \mathrm{~mL})$ and DNS reagent $(4 \mathrm{~mL})$ were mixed in a test tube and the test tube was placed in a boiling water bath for $5 \mathrm{~min}$. The tube was placed in ice to instantly cool and then laid in a room temperature water bath $\left(25^{\circ} \mathrm{C}\right)$. Finally, the absorbance was measured at $540 \mathrm{~nm}$ using a Genesys 20 spectrophotometer (Thermo Fisher Scientific Inc., Waltham, MA, USA). One unit of Pectinex Ultra SP-L enzyme was defined as the amount of enzyme that produced $1 \mu \mathrm{mol} \cdot \mathrm{min}^{-1}$ of fructose.

\subsection{Production of FOS Using Ultrasonication and Microbubbles}

Brown sugar was dissolved in $0.1 \mathrm{M}$ sodium acetate buffer $(\mathrm{pH}$ 6.5) with a final concentration of $70 \%(w / v)$. The solution $(98 \mathrm{~mL})$ was incubated at $55^{\circ} \mathrm{C}$ for $1-2 \mathrm{~h}$, then Pectinex Ultra SP-L was added with a final volume of $100 \mathrm{~mL}$ in a $250-\mathrm{mL}$ Erlenmeyer flask. The reaction was performed at $55^{\circ} \mathrm{C}$ with ultrasonication ( $37 \mathrm{kHz}$ ) using an ultrasonic bath (Elmasonic S $30 \mathrm{H}$, Elma Schmidbauer GmbH, Singen, Germeny) and then microbubbles were applied direct into the solution using a microbubble generator with a flow rate of $100 \mathrm{~mL} \cdot \mathrm{min}^{-1}$ and pressure of $0.25-0.5 \mathrm{mPa}$. When the reaction was stopped by incubation in boiling water, the FOS content in each sample was analysed using HPLC. For large scale production, the reaction was done in 1.5- and 5-L batches, and samples were collected every $1 \mathrm{~h}$ for $6 \mathrm{~h}$. The FOS content in samples were analysed using HPLC and compared to a $100-\mathrm{mL}$ scale.

\subsection{Optimisation of FOS Production}

In this study, a Box-Behnken experimental design with three levels of three factors and response surface methodology was used to estimate optimal levels of variables. The three factors with three levels for FOS production included ultrasonication time $\left(X_{1}, 2.00-15.00 \mathrm{~min}\right)$, microbubble time $\left(X_{2}, 5.00-30.00 \mathrm{~min}\right)$, and reaction time $\left(X_{3}, 2.00-6.00 \mathrm{~h}\right)$. Design expert 6.0.10 (Stat-Ease, Inc., Minneapolis, MN, USA) was used for experimental design and modelling analysis resulting in a total 
of 17 experiments, which were conducted in triplicate (Table 1). The model predicting the optimal values was expressed as Equation (1) given below:

$$
Y=\beta_{0}+\sum_{i=1}^{k} \beta_{i} X_{i}+\sum_{i=1}^{k} \beta_{i i} X_{i}^{2}+\sum_{i \geq j}^{k} \sum_{i=1}^{k} \beta_{i j} X_{i j} X_{j}
$$

where $Y$ is the predicted response, $\beta$ is the regression coefficient and $X$ is the independent variable. The $F$-value determined the statistical significance of the equation. The accuracy of the polynomial model equation was expressed by the coefficient of determination $\left(R^{2}\right)$.

Table 1. The Box-Behnken experimental design and experimental values of enzymatic activity and FOS yields produced from brown sugar.

\begin{tabular}{|c|c|c|c|c|c|c|c|c|}
\hline \multirow{2}{*}{ Run } & \multicolumn{3}{|c|}{ Variable } & \multirow{2}{*}{$\begin{array}{l}\text { Enzyme } \\
\text { Activity } \\
\left(\mathrm{U} \cdot \mathrm{mL}^{-1}\right)\end{array}$} & \multicolumn{4}{|c|}{ Oligosaccharide Yields $\left(\mathrm{mg} \cdot \mathrm{g}^{-1}\right)$} \\
\hline & $X_{1}(\min ) *$ & $X_{2}(\min )^{* *}$ & $X_{3}(\mathrm{~h}) * * *$ & & 1-Kestose & Nystose & $1^{\mathrm{F}}-\beta$-Fructofuranosylnystose & Total FOS \\
\hline 1 & 2.00 & 5.00 & 4.00 & $102.03 \pm 1.88$ & $379.80 \pm 23.15$ & $112.84 \pm 1.55$ & $10.30 \pm 0.06$ & $502.94 \pm 35.46$ \\
\hline 2 & 15.00 & 5.00 & 4.00 & $97.75 \pm 4.10$ & $371.04 \pm 34.06$ & $108.94 \pm 2.33$ & $12.24 \pm 0.15$ & $492.22 \pm 26.12$ \\
\hline 3 & 2.00 & 30.00 & 4.00 & $91.44 \pm 2.30$ & $351.19 \pm 28.85$ & $95.27 \pm 1.69$ & $8.31 \pm 0.25$ & $454.77 \pm 44.59$ \\
\hline 4 & 15.00 & 30.00 & 4.00 & $95.13 \pm 4.50$ & $362.96 \pm 49.73$ & $103.95 \pm 2.03$ & $9.14 \pm 0.59$ & $476.05 \pm 36.21$ \\
\hline 5 & 2.00 & 17.50 & 2.00 & $64.82 \pm 0.98$ & $311.30 \pm 32.11$ & $41.36 \pm 0.96$ & $2.09 \pm 0.06$ & $354.74 \pm 25.89$ \\
\hline 6 & 15.00 & 17.50 & 2.00 & $70.88 \pm 2.10$ & $330.06 \pm 44.53$ & $52.42 \pm 1.12$ & $3.02 \pm 0.12$ & $385.50 \pm 38.01$ \\
\hline 7 & 2.00 & 17.50 & 6.00 & $102.67 \pm 2.71$ & $341.32 \pm 25.85$ & $146.26 \pm 3.54$ & $18.65 \pm 1.06$ & $506.26 \pm 46.04$ \\
\hline 8 & 15.00 & 17.50 & 6.00 & $112.22 \pm 2.50$ & $352.25 \pm 25.40$ & $148.59 \pm 3.59$ & $24.61 \pm 2.09$ & $525.45 \pm 56.09$ \\
\hline 9 & 8.50 & 5.00 & 2.00 & $73.95 \pm 2.59$ & $313.25 \pm 35.33$ & $55.56 \pm 0.58$ & $2.96 \pm 0.08$ & $371.77 \pm 34.56$ \\
\hline 10 & 8.50 & 30.00 & 2.00 & $70.87 \pm 3.50$ & $313.25 \pm 27.56$ & $50.43 \pm 0.49$ & $2.65 \pm 0.11$ & $366.32 \pm 23.15$ \\
\hline 11 & 8.50 & 5.00 & 6.00 & $104.07 \pm 3.15$ & $358.53 \pm 16.81$ & $143.10 \pm 4.32$ & $17.28 \pm 0.56$ & $518.92 \pm 35.11$ \\
\hline 12 & 8.50 & 30.00 & 6.00 & $105.04 \pm 4.97$ & $356.39 \pm 40.74$ & $149.94 \pm 2.51$ & $18.67 \pm 0.92$ & $525.00 \pm 43.65$ \\
\hline 13 & 8.50 & 17.50 & 4.00 & $94.47 \pm 1.39$ & $367.94 \pm 32.00$ & $100.38 \pm 2.09$ & $8.32 \pm 0.49$ & $476.64 \pm 35.28$ \\
\hline 14 & 8.50 & 17.50 & 4.00 & $99.41 \pm 6.83$ & $361.44 \pm 42.75$ & $120.14 \pm 3.05$ & $12.75 \pm 0.46$ & $494.33 \pm 43.19$ \\
\hline 15 & 8.50 & 17.50 & 4.00 & $95.86 \pm 2.11$ & $354.56 \pm 41.56$ & $111.06 \pm 1.54$ & $10.62 \pm 0.54$ & $476.24 \pm 54.56$ \\
\hline 16 & 8.50 & 17.50 & 4.00 & $95.60 \pm 3.25$ & $365.72 \pm 26.35$ & $109.90 \pm 4.56$ & $12.26 \pm 0.83$ & $487.89 \pm 35.21$ \\
\hline 17 & 8.50 & 17.50 & 4.00 & $98.66 \pm 2.17$ & $359.31 \pm 25.50$ & $122.59 \pm 3.97$ & $12.89 \pm 0.49$ & $494.79 \pm 43.54$ \\
\hline
\end{tabular}

${ }^{*} X_{1}$, ultrasonication time; ${ }^{* *} X_{2}$, Microbubble time; ${ }^{* * *} X_{3}$, Reaction time.

\subsection{Characterisation of FOS}

The samples were filtered through a cellulose acetate membrane $(0.22 \mu \mathrm{m}$; Sartorious, Göttingen, Germany) and then subjected to high-performance liquid chromatography (HPLC; HPLC 1260, Agilent Technology, Santa Clara, CA, USA) equipped with an Asahipak NH2P-50 4E column $(5 \mu \mathrm{m}, 250 \times 4.6 \mathrm{~mm}$; Showa Denko, Tokyo, Japan) and a refractive index (RI) detector. A mixture of acetonitrile and water (70:30) was used as a mobile phase at a flow rate of $1 \mathrm{~mL} \cdot \mathrm{min}^{-1}$ for $25 \mathrm{~min}$. The column thermostat was $40^{\circ} \mathrm{C}$ [36]. Peak identification and quantification of 1-kestose, nystose, $1^{\mathrm{F}}-\beta$-fructofuranosylnystose, sucrose, glucose, and fructose in samples were estimated from the calibration curve, which was built with standard reference sugars (Wako Pure Chemical Industries, Osaka, Japan) under the same HPLC conditions.

\subsection{Statistical Analysis}

All experiments were conducted in triplicate and the results were expressed as the mean \pm standard deviations (SD). Statistical analysis of the results was performed using the SPSS statistical programme (version 17.0, IBM, Armonk, NY, USA). One-way analysis of variance (ANOVA), followed by Duncan's multiple range test, was carried out, and the differences between individual means were assessed at $p \leq 0.05$.

\section{Results and Discussion}

\subsection{Production of FOS}

FOS were synthesised from brown sugar using a combination of ultrasonication and microbubbles, in which the Box-Behnken design was used. Actual values of enzyme activity and FOS yield (1-kestose, 
nystose, $1^{\mathrm{F}}-\beta$-fructofuranosylnystose, and total FOS) obtained from an experimental design are shown in Table 1. Run 8 with $15 \mathrm{~min}$ of ultrasonication, $17.50 \mathrm{~min}$ of microbubbles and a $6.00 \mathrm{~h}$ reaction time led to the highest enzyme activity and a yield of $1^{\mathrm{F}}-\beta$-fructofuranosylnystose and total FOS, which were $112.22 \pm 2.50 \mathrm{U} \cdot \mathrm{mL}^{-1}, 24.61 \pm 2.09 \mathrm{mg} \cdot \mathrm{g}^{-1}$, and $525.45 \pm 56.09 \mathrm{mg} \cdot \mathrm{g}^{-1}$, respectively. Meanwhile, the highest yield of 1-kestose and nystose were obtained from Run 1 and Run 12, respectively, where the conditions were $2.00 \mathrm{~min}$ of ultrasonication, $5.00 \mathrm{~min}$ of microbubbles, and a $4.00 \mathrm{~h}$ reaction time for Run 1 and $8.50 \mathrm{~min}$ of ultrasonication, $30.00 \mathrm{~min}$ of microbubbles, and reaction time of $6.00 \mathrm{~h}$ for Run 12.

In addition, the relationship between the three variables $\left(X_{1}, X_{2}\right.$ and $\left.X_{3}\right)$ and the responses were analysed by ANOVA, which are shown in Table 2. According to the analysis, the reaction time $\left(X_{3}\right)$ was the most significant variable for Pectinex Ultra SP-L activity and production yield of 1-kestose, nystose, $1^{\mathrm{F}}$ - $\beta$-fructofuranosylnystose and total FOS. Moreover, the quadratic term, reaction time $\left(\mathrm{X}_{3}{ }^{2}\right)$ displayed the most significant effect on enzyme activity and yield of 1-kestose and total FOS. However, there were no interactive effects and quadratic terms that had a significant effect on the yield of nystose and $1^{\mathrm{F}}-\beta$-fructofuranosylnystose.

Table 2. Analysis of variance (ANOVA) for the response surface quadratic model for FOS production.

\begin{tabular}{|c|c|c|c|c|c|c|c|c|c|c|}
\hline & \multicolumn{2}{|c|}{ Enzyme Activity } & \multicolumn{2}{|c|}{ 1-Kestose } & \multicolumn{2}{|c|}{ Nystose } & \multicolumn{2}{|c|}{$1^{\mathrm{F}}-\beta$-Fructofuranosylnystose } & \multicolumn{2}{|c|}{ Total FOS } \\
\hline & $F$ Value & $p$ Value & $F$ Value & $p$ Value & $F$ Value & $p$ Value & $F$ Value & $p$ Value & $F$ Value & $p$ Value \\
\hline Model & 24.57 & 0.0002 & 8.64 & 0.0048 & 75.78 & $<0.0001$ & 54.54 & $<0.0001$ & 42.45 & $<0.0001$ \\
\hline$X_{1}^{*}$ & 2.10 & 0.1904 & 0.985 & 0.354 & 2.13 & 0.168 & 3.18 & 0.0979 & 1.58 & 0.248 \\
\hline$X_{2}^{* *}$ & 2.18 & 0.1832 & 2.87 & 0.134 & 0.573 & 0.462 & 0.545 & 0.473 & 3.78 & 0.0931 \\
\hline$X_{3}^{* * *}$ & 191.53 & $<0.0001$ & 27.92 & 0.0011 & 224.63 & $<0.0001$ & 159.89 & $<0.0001$ & 310.96 & $<0.0001$ \\
\hline$X_{1} X_{2}$ & 1.18 & 0.3135 & 2.03 & 0.197 & & & & & 1.91 & 0.210 \\
\hline$X_{1} X_{3}$ & 0.225 & 0.6494 & 0.173 & 0.690 & & & & & 1.76 & 0.226 \\
\hline$X_{2} X_{3}$ & 0.304 & 0.5984 & 0.0128 & 0.913 & & & & & 0.247 & 0.634 \\
\hline$X_{1}^{2}$ & 0.0859 & 0.7780 & 0.230 & 0.646 & & & & & 1.66 & 0.239 \\
\hline$X_{2}^{2}$ & 0.0307 & 0.8660 & 0.694 & 0.432 & & & & & 0.00004 & 0.995 \\
\hline$X_{3}^{2}$ & 23.34 & 0.0019 & 43.55 & 0.0003 & & & & & 58.68 & 0.0001 \\
\hline Lack of Fit & 5.61 & 0.0645 & 6.06 & 0.0572 & 1.27 & 0.438 & 0.981 & 0.553 & 4.34 & 0.0951 \\
\hline
\end{tabular}

Considering the significant terms, enzyme activity and FOS yield could be described by the mathematical equations obtained in terms of coded variables. The predictive equations and statistical data are shown in Table 3. In the equations, a positive (+) coefficient indicates a synergistic effect, whereas a negative sign (-) refers to an antagonistic effect. According to the mathematical equations, the most significant variable was $X_{3}$ (reaction time) because it had a positive effect on all responses. Moreover, $X_{1}$ (ultrasonication time) also had a positive effect on the yield of nystose and $1^{\mathrm{F}}-\beta$-fructofuranosylnystose. However, the interaction of the three variables showed both positive and negative effects.

Table 3. Analysis of variance (ANOVA) of the model and coefficient estimates for response parameters.

\begin{tabular}{|c|c|c|c|c|c|c|c|}
\hline Response & Final Equation in Term of Actual Factors & $P^{*}$ & LOF & $R^{2}$ & Adj. $R^{2}$ & AP & $\mathrm{CV}$ \\
\hline Enzyme activity & $\begin{array}{l}35.10-0.20 \times X_{1}-0.59 \times X_{2}+24.95 \times X_{3}-0.012 \times X_{1}^{2} \\
+0.002 \times X_{2}^{2}-2.16 \times X_{3}^{2}+0.024 \times X_{1} \times X_{2}+0.07 \times \\
X_{1} \times X_{3}+0.04 \times X_{2} \times X_{3}\end{array}$ & 0.0002 & 0.0645 & 0.9693 & 0.9299 & 14.480 & 3.96 \\
\hline 1-Kestose & $\begin{array}{l}226.07-1.22 \times X_{1}-1.92 \times X_{2}+70.97 \times X_{3}+0.01 \times \\
X_{1}^{2}+0.02 \times X_{2}^{2}-7.57 \times X_{3}^{2}+0.08 \times X_{1} \times X_{2}-0.15 \times \\
X_{1} \times X_{3}-0.02 \times X_{2} \times X_{3}\end{array}$ & 0.0048 & 0.0572 & 0.9175 & 0.8113 & 9.140 & 2.69 \\
\hline Nystose & $12141+0.77 \times X_{1}-0.21 \times X_{2}+25.63 \times X_{3}$ & $<0.0001$ & 0.4385 & 0.9459 & 0.9334 & 23.978 & 9.17 \\
\hline $1^{\mathrm{F}}-\beta$-Fructofuranosyl-nystose & $-7.02+0.19 \times X_{1}-0.04 \times X_{2}+4.28 \times X_{3}$ & $<0.0001$ & 0.5529 & 0.9264 & 0.9094 & 21.032 & 17.44 \\
\hline Total FOS & $\begin{array}{l}165.75+4.35 \times X_{1}-1.94 \times X_{2}+125.68 \times X_{3}-0.17 \times \\
X_{1}^{2}+0.0002 \times X_{2}^{2}-10.82 \times X_{3}^{2}+0.10 \times X_{1} \times \\
X_{2}-0.59 \times X_{1} \times X_{3}+0.12 \times X_{2} \times X_{3}\end{array}$ & $<0.0001$ & 0.0951 & 0.9820 & 0.9589 & 19.098 & 2.49 \\
\hline
\end{tabular}

${ }^{*} P$, probability of error; $\mathrm{LOF}$, lack of fit; Adj. $R^{2}$, adjust $R^{2}$; $\mathrm{AP}$, adequate precision; $\mathrm{CV}$, coefficient of variance. 
The relationships between three variables and responses (enzyme activity, 1-kestose, nystose, $1^{\mathrm{F}}-\beta$-fructofuranosylnystose and total FOS) are shown in Figure 1. The Pectinex Ultra SP-L activity (Figure 1a-c) and the yield of total FOS (Figure 1d-f) and 1-kestose (Figure 1g-i) increased when the reaction time $\left(X_{3}\right)$ was increased to $4-5 \mathrm{~h}$. Moreover, ultrasonication time $\left(X_{1}\right)$ led to an increased yield of nystose (Figure $1 \mathrm{j}$ ) and $1^{\mathrm{F}}$ - $\beta$-fructofuranosylnystose (Figure $1 \mathrm{k}$ ), while microbubbles $\left(\mathrm{X}_{2}\right)$ had no effect on them.
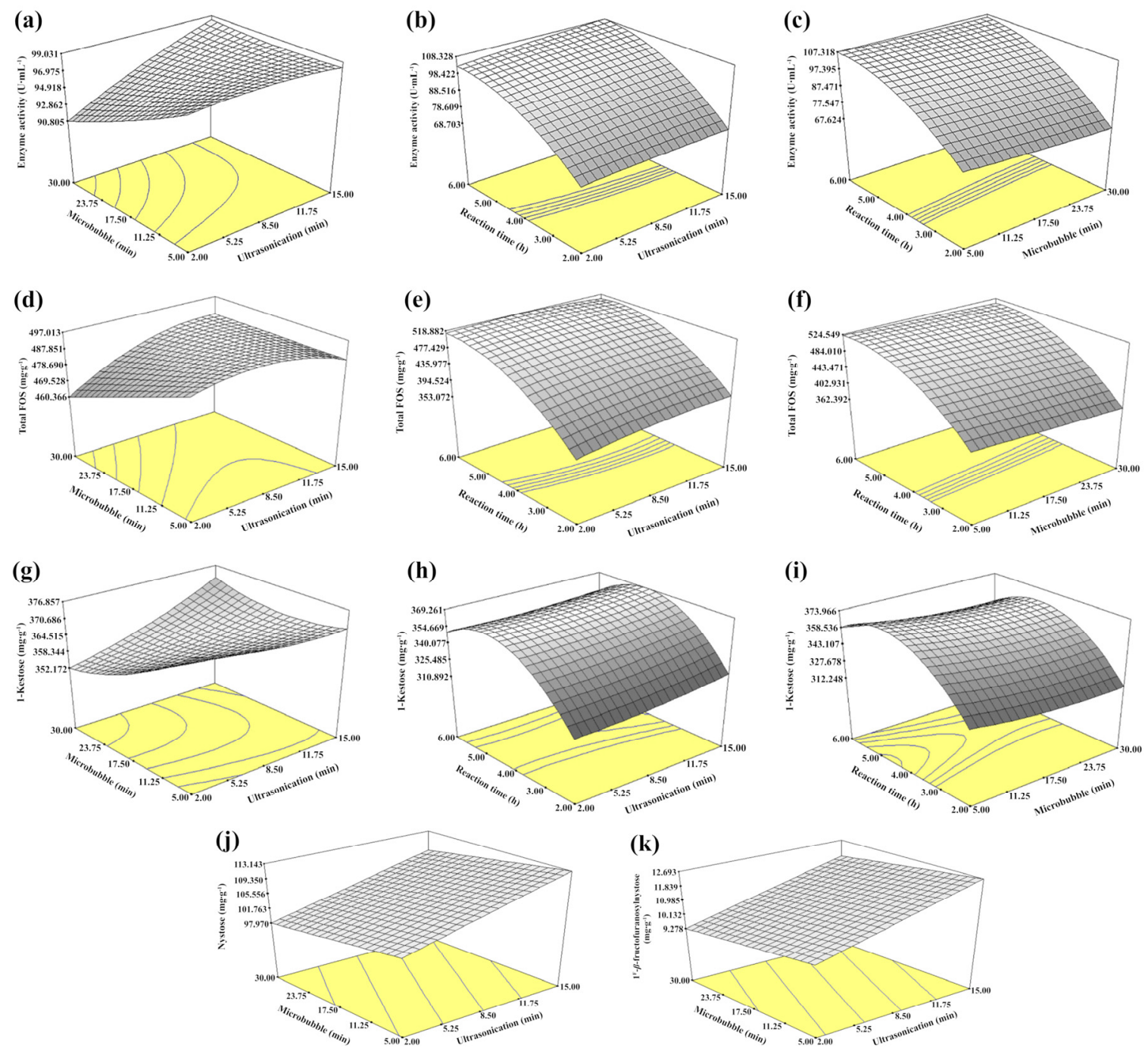

Figure 1. Response surface plots of the relationship between three variables (ultrasonication, microbubble and reaction time), (a-c) enzyme activity, (d-f) total FOS; (g-i) 1-kestose, (j) nystose, (k) $1^{\mathrm{F}}$ - $\beta$-fructofuranosylnystose.

\subsection{Optimisation of FOS Production}

Based on the experimental designs, the optimum conditions for FOS production from brown sugar using ultrasonication and microbubbles were; (1) ultrasonication for $5 \min 45 \mathrm{~s}$, (2) microbubbles for $7 \mathrm{~min} 19 \mathrm{~s}$, and (3) reaction time of $5 \mathrm{~h} 40 \mathrm{~min}$. Under the optimum conditions, the predictive enzyme activity was $106.71 \mathrm{U} \cdot \mathrm{mL}^{-1}$ and the predictive yield of kestose, nystose, $1^{\mathrm{F}}-\beta$-fructofuranosylnystose and total FOS were $365.25,147.92,17.92$ and $525.44 \mathrm{mg} \cdot \mathrm{g}^{-1}$, respectively. To validate the optimum conditions, validation experiments were performed using white sugar and brown sugar as substrates. The actual values obtained from experiments under each set of conditions are shown in Table 4 . The combination of ultrasonication and microbubbles enhanced the Pectinex Ultra SP-L activity up to $102.51 \pm 4.69 \mathrm{U} \cdot \mathrm{mL}^{-1}$, which produced a total FOS yield of $494.89 \pm 19.98 \mathrm{mg} \cdot \mathrm{g}^{-1}$ substrate using brown 
sugar. For white sugar, the enzyme activity was $107.93 \pm 5.26 \mathrm{U} \cdot \mathrm{mL}^{-1}$ and total FOS yield was increased to $580.01 \pm 21.35 \mathrm{mg} \cdot \mathrm{g}^{-1}$ substrate. When the ultrasonication was performed without microbubbles, the enzyme activity and total FOS yield were decreased. This result confirmed that a microbubble step was important for the production. According to a previous report, Pectinex Ultra SP-L activity under normal conditions was $22 \mathrm{U} \cdot \mathrm{mL}^{-1}$ [5]. Therefore, Pectinex Ultra SP-L activity was increased by $366 \%$ and $390 \%$ for brown sugar and white sugar, respectively, when the combined ultrasonication and microbubble were performed. Noticeably, white sugar led to a higher enzyme activity and total FOS yield than brown sugar (Table 4). Thus, white sugar was appropriate to use as a substrate for FOS production. Brown sugar contains sucrose, glucose, and fructose. Glucose in brown sugar could inhibit fructosyltransferase activity via feedback inhibition, so total FOS yield was lower [21]. According to the validation, the error was $5.18 \%$ between the predicted model and experimental values. $\mathrm{Hu}$ [37] reported that the error value should be less than $10 \%$, so the model was acceptable to predict the production of FOS using Pectinex Ultra SP-L with a combination of ultrasonication and microbubbles.

Table 4. Fructooligosaccharide (FOS) yields produced under optimal conditions: $\left(X_{1}\right)$ ultrasonication $5 \mathrm{~min} 45 \mathrm{~s},\left(X_{2}\right)$ microbubble $7 \mathrm{~min} 19 \mathrm{~s}$, and $\left(X_{3}\right)$ reaction time of $5 \mathrm{~h} 40 \mathrm{~min}$.

\begin{tabular}{|c|c|c|c|c|c|}
\hline \multirow{2}{*}{ Factors } & \multirow{2}{*}{$\begin{array}{l}\text { Pectinex Ultra } \\
\text { SP-L Activity } \\
\left(\mathrm{U} \cdot \mathrm{mL}^{-1}\right)\end{array}$} & \multicolumn{4}{|c|}{ Fructooligosaccharide Yields (mg.g ${ }^{-1}$ ) } \\
\hline & & 1-Kestose & Nystose & $1^{\mathrm{F}}-\beta$-Fructofurano-sylnystose & Total FOS \\
\hline $\begin{array}{l}\text { Brown sugar using a } \\
\text { combination of } \\
\text { ultrasonication and } \\
\text { microbubble }\end{array}$ & $102.51 \pm 4.69$ & $368.02 \pm 20.22$ & $110.53 \pm 8.81$ & $16.35 \pm 1.49$ & $494.89 \pm 19.98$ \\
\hline $\begin{array}{l}\text { White sugar using a } \\
\text { combination of } \\
\text { ultrasonication and } \\
\text { microbubbles }\end{array}$ & $107.93 \pm 5.26$ & $415.02 \pm 19.54$ & $147.50 \pm 9.84$ & $17.49 \pm 2.94$ & $580.01 \pm 21.35$ \\
\hline $\begin{array}{l}\text { White sugar using } \\
\text { only ultrasonication }\end{array}$ & $90.05 \pm 3.54$ & $399.48 \pm 21.33$ & $103.83 \pm 12.33$ & $10.23 \pm 1.66$ & $515.53 \pm 20.43$ \\
\hline
\end{tabular}

\subsection{Production of FOS in a Large Scale}

The scale-up of FOS production was performed at 0.1, 1.5 and 5.0-L scales under the optimum conditions described above. The samples were collected every $1 \mathrm{~h}$ for a total of $6 \mathrm{~h}$ (Figure 2). At the $100-\mathrm{mL}$ scale, the maximum yield of 1-kestose, nystose, $1^{\mathrm{F}}-\beta$-fructofuranosylnystose, and total FOS were obtained at 4, 6, 6, and $5 \mathrm{~h}$ reaction time, respectively. When a volume of 1.5-L production was used, the optimum reaction time was $4,4,3$ and $4 \mathrm{~h}$ for 1-kestose, nystose, $1^{\mathrm{F}}$ - $\beta$-fructofuranosyl-nystose, and total FOS, respectively. While the maximum yield of 1-kestose, nystose, $1^{\mathrm{F}}-\beta$-fructofuranosylnystose, and total FOS at the 5 -L scale occurred at $4,6,6$ and $4 \mathrm{~h}$ reaction time, respectively. In the $100-\mathrm{mL}$ batch, the highest total FOS yield was $462.34 \pm 24.22 \mathrm{mg} \cdot \mathrm{g}^{-1}$ substrate at a $5 \mathrm{~h}$ reaction. While the optimum reaction time of the enlarge production scale $(1.5$ and $5 \mathrm{~L})$ decreased to $4 \mathrm{~h}$, the maximum yields of total FOS were $459.24 \pm 25.64$ and $452.55 \pm 19.53 \mathrm{mg} \cdot \mathrm{g}^{-1}$ substrate, respectively (Figure 2a). Thus, the enlarged production took a short reaction time than $100-\mathrm{mL}$ production. Interestingly, the FOS yields produced in a 1.5-L batch were much higher than other batches at the optimum reaction time (Figure 2a,c,d). Therefore, 1.5-L scale might be appropriate for FOS production from brown sugar and the enlarged production scale decreased the reaction time, compared to the 100-mL scale.

In comparison, the total FOS yield from brown sugar was $0.45 \mathrm{~g} \cdot \mathrm{g}^{-1}$ substrate, which was lower than that of white sugar $\left(0.58 \mathrm{~g} \cdot \mathrm{g}^{-1}\right.$ substrate). Despite a low FOS yield, brown sugar had a shorter reaction time $(4 \mathrm{~h})$ than white sugar $(5.67 \mathrm{~h})$. Table 5 presents the total FOS yield obtained from this study in comparison to other studies. In previous studies, they used the conventional method and ultra-high pressure (UHP)-assisted method to synthesise FOS from sugar. The UHP.assisted method took the shortest reaction time $(15 \mathrm{~min})$ and had a total FOS yield of $0.57 \mathrm{~g} \cdot \mathrm{g}^{-1}$ substrate [5]. Among the conventional method, FOS yield ranged from 0.55 to $0.67 \mathrm{~g} \cdot \mathrm{g}^{-1}$ substrate within a reaction time of 5.6 
to $16 \mathrm{~h}$ [38-43]. Although the FOS yield from this study was lower, the reaction time was reduced. The normal reaction time in the conventional method was $\sim 10 \mathrm{~h}$ when using Pectinex Ultra SP-L in the synthesis. Here we found that the use of ultrasonication and microbubbles could decrease reaction time by $60 \%$.

(a)

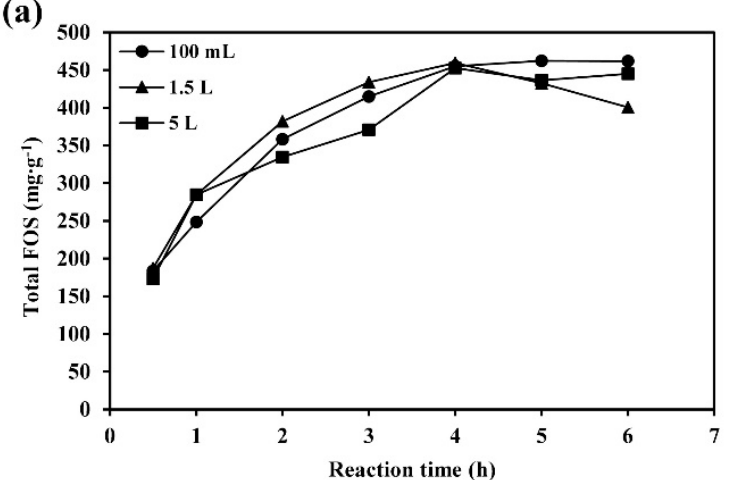

(c)

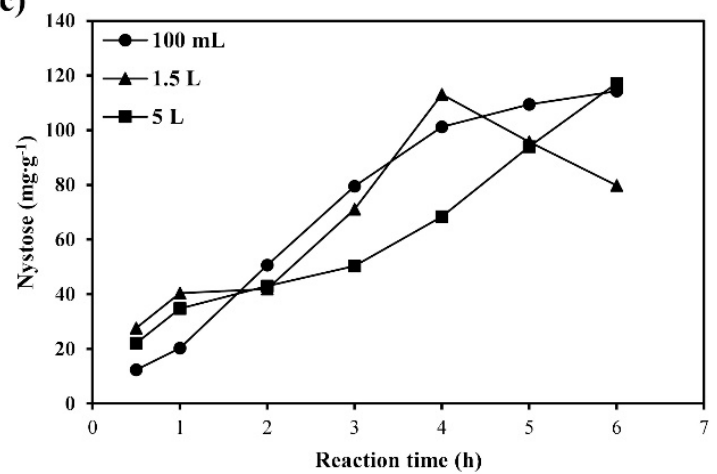

(b)

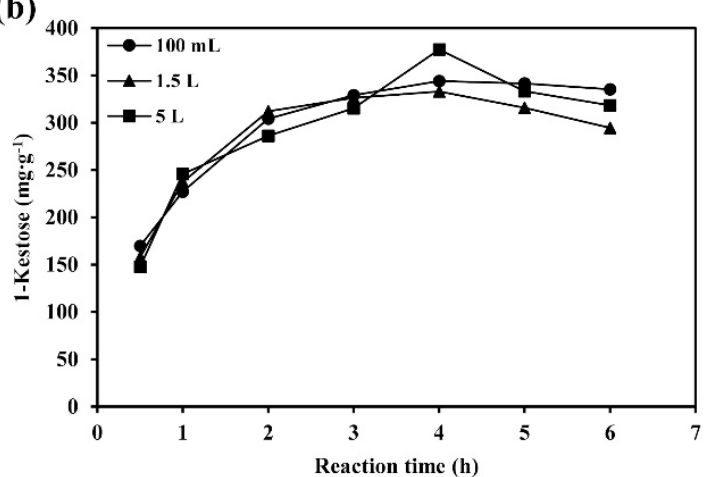

(d)

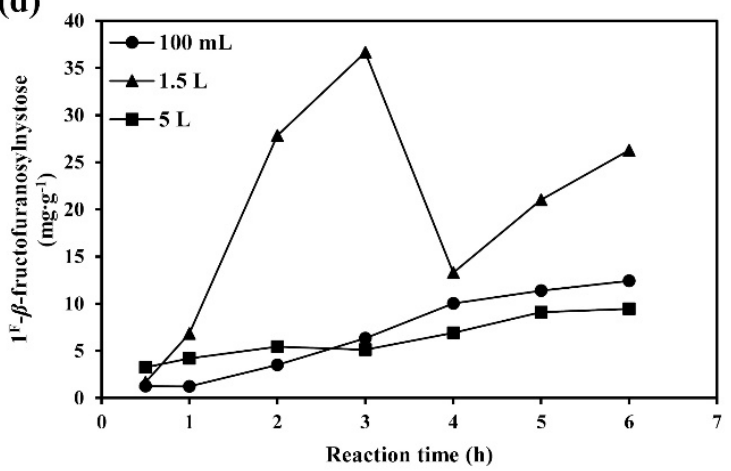

Figure 2. Fructooligosaccharide production from brown sugar in $100 \mathrm{~mL}, 1.5 \mathrm{~L}$ and $5 \mathrm{~L}$ batches. (a) Total FOS yield, (b) 1-Kestose yield, (c) Nystose yield, and (d) $1^{\mathrm{F}}-\beta$-fructofuranosylnystose yield.

Table 5. Comparison of FOS production from this study and other reports.

\begin{tabular}{|c|c|c|c|c|c|}
\hline Substrate & Enzyme & Condition & Reaction Time (h) & $\begin{array}{c}\text { FOS Yield } \\
\left(\mathrm{g} \cdot \mathrm{g}^{-1} \text { Substrate }\right)\end{array}$ & Reference \\
\hline Brown sugar & Pectinex Ultra SP-L & $\begin{array}{l}\text { Ultrasonication and microbubble, } \\
55^{\circ} \mathrm{C}, 700 \mathrm{~g} \cdot \mathrm{L}^{-1} \text { substrate }\end{array}$ & 4 & 0.45 & This study \\
\hline White sugar & Pectinex Ultra SP-L & $\begin{array}{l}\text { Ultrasonication and microbubble, } \\
55^{\circ} \mathrm{C}, 700 \mathrm{~g} \cdot \mathrm{L}^{-1} \text { substrate }\end{array}$ & 5.67 & 0.58 & This study \\
\hline White sugar & $\begin{array}{c}\text { GAPfopA_V1 } \\
\text { (engineered } \\
\beta \text {-fructofuronosidase) }\end{array}$ & $\begin{array}{l}\text { Water bath, } 62^{\circ} \mathrm{C}, 120 \mathrm{rpm}, \\
600 \mathrm{~g} \cdot \mathrm{L}^{-1} \text { substrate }\end{array}$ & 5. 6 & 0.55 & [43] \\
\hline White sugar & Pectinex Ultra SP-L & $\begin{array}{l}\text { Ultra-high pressure at } 300 \mathrm{MPa} \text {, } \\
30^{\circ} \mathrm{C}, 600 \mathrm{~g} \cdot \mathrm{L}^{-1} \text { substrate }\end{array}$ & 0.25 & 0.57 & [5] \\
\hline $\begin{array}{l}\text { White sugar } \\
\text { and Jerusalem } \\
\text { artichoke }\end{array}$ & Inulinase & $\begin{array}{l}\text { Water bath, } 55^{\circ} \mathrm{C}, 59.4 \mathrm{~g} \cdot \mathrm{L}^{-1} \text { inulin } \\
\text { and } 598.7 \mathrm{~g} \cdot \mathrm{L}^{-1} \text { refine sugar }\end{array}$ & 9 & 0.67 & [38] \\
\hline White sugar & Pectinex Ultra SP-L & $\begin{array}{c}\text { Water bath, } 60^{\circ} \mathrm{C}, 400 \mathrm{~g} \cdot \mathrm{L}^{-1} \\
\text { substrate }\end{array}$ & 16 & 0.62 & [39] \\
\hline White sugar & Pectinex Ultra SP-L & $\begin{array}{l}\text { Water bath, } 55^{\circ} \mathrm{C}, 500 \mathrm{~g} \cdot \mathrm{L}^{-1} \\
\text { substrate }\end{array}$ & 10 & 0.60 & [40] \\
\hline White sugar & Pectinex Ultra SP-L & $\begin{array}{c}\text { Water bath, } 50^{\circ} \mathrm{C}, 536.2 \mathrm{~g} \cdot \mathrm{L}^{-1} \\
\text { substrate }\end{array}$ & 6 & 0.59 & [41] \\
\hline White sugar & $\begin{array}{l}\text { Culture fluid of } \\
\text { Aspergillus oryzae } \\
\text { CFR202 }\end{array}$ & $\begin{array}{l}\text { Water bath, } 55^{\circ} \mathrm{C}, 64.55 \mathrm{~g} \cdot \mathrm{L}^{-1} \\
\text { substrate }\end{array}$ & 12 & 0.58 & [42] \\
\hline
\end{tabular}

This study demonstrated that the combination of ultrasonication and microbubbles could enhance FOS concentration and productivity compared to the conventional method (Table 6). In $4 \mathrm{~h}$ of reaction time, the combined methods gave the maximum concentration of 1-kestose $\left(264.1 \mathrm{~g} \cdot \mathrm{L}^{-1}\right)$ and total FOS $\left(316.8 \mathrm{~g} \cdot \mathrm{L}^{-1}\right)$, which also had the highest productivity $\left(66.0\right.$ and $79.2 \mathrm{~g} \cdot \mathrm{L}^{-1} \cdot \mathrm{h}^{-1}$, respectively). 
Conversely, the concentration and productivity of nystose and $1^{\mathrm{F}}-\beta$-fructofuronosyl nystose were lower than in previous studies. This confirmed that using the combined methods had a higher productivity of FOS from brown sugar, despite a low FOS yield. Although the UHP-assisted approach produced the highest productivity of FOS, this method required complex high-pressure equipment systems and consumed a lot of energy due to extreme pressure [5]. In contrast, the ultrasonication and microbubble techniques were simple methods with mild conditions that consumed less energy. Additionally, these techniques have been accepted as cost-effective and eco-friendly processes [28]. Consequently, this method was suitable to apply on an industrial scale for FOS production. Many studies have reported that ultrasound at an appropriate frequency led to changes in enzyme conformation. The conformational changes had important roles in catalysis. A new conformation might enhance binding with substrates, therefore increasing enzyme activity $[28,29,44]$.

Table 6. Fructooligosaccharide (FOS) yield and productivity obtained from this study compared to other reports.

\begin{tabular}{|c|c|c|c|c|c|c|c|c|c|c|}
\hline \multirow{3}{*}{ Method } & \multirow{3}{*}{$\begin{array}{l}\text { Reaction } \\
\text { Time (h) }\end{array}$} & \multicolumn{8}{|c|}{ Fructooligosaccharide } & \multirow{3}{*}{ Reference } \\
\hline & & \multicolumn{4}{|c|}{ Concentration $\left(g \cdot \mathrm{L}^{-1}\right)$} & \multicolumn{4}{|c|}{ Productivity $\left(\mathrm{g} \cdot \mathrm{L}^{-1} \cdot \mathrm{h}^{-1}\right)$} & \\
\hline & & $\mathrm{GF}_{2} *$ & $\mathrm{GF}_{3}$ & $\mathrm{GF}_{4}$ & Total FOS & $\mathrm{GF}_{2}$ & $\mathrm{GF}_{3}$ & $\mathrm{GF}_{4}$ & Total FOS & \\
\hline $\begin{array}{l}\text { Ultrasonic } \\
\text { and } \\
\text { microbubble } \\
\text { methods }\end{array}$ & 4 & 264.1 & 47.8 & 4.84 & 316.8 & 66.0 & 11.96 & 1.21 & 79.2 & This study \\
\hline $\begin{array}{l}\text { Ultra-high } \\
\text { pressure } \\
\text { (UHP) } \\
\text { method }\end{array}$ & 0.25 & 189.72 & 110.88 & 28.2 & 328.8 & 758.88 & 443.52 & 112.8 & 1315.2 & [5] \\
\hline $\begin{array}{l}\text { Conventional } \\
\text { methods }\end{array}$ & $\begin{array}{c}5.6 \\
9 \\
10 \\
6 \\
12\end{array}$ & $\begin{array}{c}220.8 \\
156.98 \\
155 \\
212.33 \\
174.2\end{array}$ & $\begin{array}{c}321.6 \\
144.10 \\
130 \\
106.7 \\
96.6\end{array}$ & $\begin{array}{c}60.0 \\
84.63 \\
15.0 \\
8.58 \\
26.8\end{array}$ & $\begin{array}{c}330 \\
404.0 \\
300 \\
327.6 \\
297.7\end{array}$ & $\begin{array}{c}39.4 \\
17.44 \\
15.5 \\
35.4 \\
14.5\end{array}$ & $\begin{array}{c}57.4 \\
16.01 \\
13.0 \\
17.78 \\
8.05\end{array}$ & $\begin{array}{l}10.7 \\
9.40 \\
1.50 \\
1.43 \\
2.24\end{array}$ & $\begin{array}{c}58.9 \\
44.90 \\
30.0 \\
54.6 \\
24.8\end{array}$ & $\begin{array}{l}{[43]} \\
{[38]} \\
{[40]} \\
{[41]} \\
{[42]}\end{array}$ \\
\hline
\end{tabular}

With regard to microbubbles, the effect of microbubbles on enzymes and the production is still unclear and requires further investigation. Microbubbles might create turbulence in the system and increase the possibility of enzyme-substrate attachment. Based on the increased surface area of microbubbles, we speculated that microbubbles might adsorb sugar molecules on their surfaces and carry them to the catalytic sites of enzymes, thereby increasing the activity [45]. Furthermore, various reports have confirmed that high pressure has both positive and negative effects on enzyme activity. Adequate pressure can enhance enzyme activity [46], for the reason that microbubbles are unstable, are suddenly broken and gas is released. Spontaneously, pressure is generated and affects the enzyme. We suggested that the pressure from microbubbles affected enzyme activity, so FOS yields and enzyme activity were increased.

We found that the technique is useful and easy to use for FOS production and has the potential to be applied in industrial production. In the future, the combination of ultrasonication and microbubbles has the potential to increase production of other oligosaccharides, including galactooligosaccharides (GOS), xylooligosaccharides (XOS), inulooligosaccharides (IOS), and soybean oligosaccharides (SOS) and should be considered in future research.

\section{Conclusions}

The optimal conditions for FOS production from brown sugar were the ultrasonication for $5 \mathrm{~min} 45 \mathrm{~s}$, microbubbles for $7 \mathrm{~min} 19 \mathrm{~s}$, and a reaction time of $5 \mathrm{~h} 40 \mathrm{~min}$. The combination of ultrasonication and microbubbles could enhance enzyme activity, and the Pectinex Ultra SP-L activity reached $102.51 \pm 4.69 \mathrm{U} \cdot \mathrm{mL}^{-1}$. The highest yield of total FOS, 1-kestose, nystose, and $1^{\mathrm{F}}-\beta$-fructofuranosylnystose 
were $494.89 \pm 19.98,368.48 \pm 20.22,110.53 \pm 8.81$, and $16.35 \pm 1.49 \mathrm{mg} \cdot \mathrm{g}^{-1}$ substrate, respectively. On a large scale $(5 \mathrm{~L})$, the maximum yield of total FOS, 1-kestose, nystose, and $1^{\mathrm{F}}-\beta$-fructofuranosylnystose were $452.55 \pm 19.53,377.28 \pm 21.64,68.35 \pm 2.35$ and $6.92 \pm 0.09 \mathrm{mg} \cdot \mathrm{g}^{-1}$ substrate, respectively within $4 \mathrm{~h}$ of reaction. Thus, the use of ultrasonication and microbubble in FOS production using brown sugar was able to increase Pectinex Ultra SP-L activity by $366 \%$ and reduce the reaction time by $60 \%$, which productivity of FOS was enhanced.

This strategy has various advantages, such as easy and safe performance, and high efficacy. Additionally, this study uses a low-cost substrate (brown sugar) in which significantly reduces production costs and affects the economy of the process. Therefore, the use of brown sugar as a substrate with ultrasonication and microbubble assistants is an appropriate strategy for FOS production at an industrial scale.

Author Contributions: Conceptualisation, P.S., Y.P. and T.C.; funding Acquisition, P.S. and Y.P. methodology, W.C. and A.M.; software, Y.P. and K.J.; resources, P.S. and Y.P., validation, P.S., T.C., and S.Y.; formal analysis, Y.P., K.J. and T.C.; investigation, W.C. and A.M.; writing—original draft preparation, W.C.; writing-review and editing, P.S., W.P.-a. and S.Y. All authors have read and agreed to the published version of the manuscript.

Funding: The authors are grateful the financial support provided by the National Research Council of Thailand (NRCT) via the Royal Golden Jubilee PhD Programme, Thailand (Grant No. PHD/0185/2560) to Mr Worraprat Chaisuwan and Dr Phisit Seesuriyachan. P. Seesuriyachan also acknowledges partial financial supports and/or in-kind assistance from Program Management Unit - Brain Power (PMUB), The Office of National Higher Education Science Research and Innovation Policy Council (NXPO) in Global Partnership Project, Basic research fund, Thailand Science Research and Innovation (TSRI), Chiang Mai University (CMU), Faculty of Science (CoE64-P001) as well as Faculty of Agro-Industry (CMU-8392(10)/COE64), CMU.

Acknowledgments: The authors are grateful to Interdisciplinary Program in Biotechnology, Graduate School of Chiang Mai University; Cluster of Agro Bio-Circular-Green Industry (Agro BCG); Faculty of Agro-Industry and Chiang Mai University for the research infrastructure.

Conflicts of Interest: All authors declare that they have no conflict of interest with respect to the work described in this manuscript.

\section{References}

1. Noncommunicable Diseases. Available online: https://www.who.int/news-room/fact-sheets/detail/ noncommunicable-diseases. (accessed on 17 April 2020).

2. Hasler, C.M. Functional foods: Benefits, concerns and challenges-A position paper from the American Council on science and health. J. Nutr. 2002, 132, 3772-3781. [CrossRef] [PubMed]

3. Al-Sheraji, S.H.; Ismail, A.; Manap, M.Y.; Mustafa, S.; Yusof, R.M.; Hassan, F.A. Prebiotics as functional foods: A review. J. Funct. Foods 2013, 5, 1542-1553. [CrossRef]

4. Karnaouri, A.; Matsakas, L.; Krikigianni, E.; Rov, U.; Christakopoulos, P. Valorization of waste forest biomass toward the production of cello-oligosaccharides with potential prebiotic activity by utilizing customized enzyme cocktails. Biotechnol. Biofuels 2019, 12, 285. [CrossRef]

5. Kawee-Ai, A.; Chaisuwan, W.; Manassa, A.; Seesuriyachan, P. Effects of ultra-high pressure on effective synthesis of fructooligosaccharides and fructotransferase activity using Pectinex Ultra SP-L and inulinase from Aspergillus niger. Prep. Biochem. Biotechnol. 2019, 49, 649-658. [CrossRef]

6. Fructo-Oligosaccharides, GRN No. 605. Available online: https://www.accessdata.fda.gov/scripts/fdcc/?set= GRASNotices\&id=605\&sort=GRN_No\&order=DESC\&startrow=1\&type=basic\&search=fructo. (accessed on 18 April 2020).

7. Fructooligosaccharide, GRN No. 44. Available online: https://www.accessdata.fda.gov/scripts/fdcc/?set= GRASNotices\&id=44\&sort=GRN_No\&order=DESC\&startrow=1\&type=basic\&search=fructo. (accessed on 18 April 2020).

8. Campbell, J.M.; Bauer, L.L.; Fahey, G.C., Jr.; Hogarth, A.J.C.L.; Wolf, B.W.; Hunter, D.E. Selected fructooligosaccharide (1-Kestose, Nystose, and $1 \mathrm{~F}-\beta$-Fructofuranosylnystose) composition of foods and feeds. J. Agric. Food Chem. 1997, 45, 3075-3082. [CrossRef]

9. Akalın, A.S.; Fenderya, S.; Akbulut, N. Viability and activity of bifidobacteria in yoghurt containing fructooligosaccharide during refrigerated storage. Int. J. Food Sci. Tech. 2004, 39, 613-621. [CrossRef] 
10. Tanno, H.; Fujii, T.; Ose, R.; Hirano, K.; Tochio, T.; Endo, A. Characterization of fructooligosaccharidedegrading enzymes in human commensal Bifidobacterium longum and Anaerostipes caccae. Biochem. Biophys. Res. Commun. 2019, 518, 294-298. [CrossRef]

11. Liu, F.; Li, P.; Chen, M.; Luo, Y.; Prabhakar, M.; Zheng, H.; He, Y.; Qi, Q.; Long, H.; Zhang, Y.; et al. Fructooligosaccharide (FOS) and galactooligosaccharide (GOS) increase Bifidobacterium but reduce butyrate producing bacteria with adverse glycemic metabolism in healthy young population. Sci. Rep. 2017, 7, 11789. [CrossRef] [PubMed]

12. Rycroft, C.E.; Jones, M.R.; Gibson, G.R.; Rastall, R.A. A comparative in vitro evaluation of the fermentation properties of prebiotic oligosaccharides. J. Appl. Microbiol. 2001, 91, 878-887. [CrossRef] [PubMed]

13. Tang, C.; Ding, R.; Sun, J.; Liu, J.; Kan, J.; Jin, C. Impacts of natural polysaccharides on the intestinal microbiota and immune responses-A review. Food Funct. 2019, 10, 2290-2312. [CrossRef] [PubMed]

14. Buddington, R.K.; Kelly-Quangliana, K.; Buddington, K.K.; Kimura, Y. Non-digestible oligosaccharides and defense functions: Lessons learned from animal models. Br. J. Nutr. 2002, 87, S159-S162. [CrossRef]

15. Taper, H.; Roberfroid, M. Inulin/oligofructose and anticancer therapy. Br. J. Nutr. 2002, 87, S283-S286. [CrossRef] [PubMed]

16. Olesen, M.; Gudmand-Hoyer, E. Efficacy, safety, and tolerability of fructooligosaccharides in the treatment of irritable bowels syndrome. Am. J. Clin. Nutr. 2000, 72, 1570-1575. [CrossRef]

17. Yildiz, S. The metabolism of fructooligosaccharides and fructooligosaccharide-related compounds in plants. Food Rev. Int. 2010, 27, 16-50. [CrossRef]

18. Sangeetha, P.T.; Ramesh, M.N.; Prapulla, S.G. Recent trends in the microbial production, analysis and application of fructooligosaccharides. Trends Food Sci. Technol. 2005, 16, 442-457.

19. Surin, S.; Seesuriyachan, P.; Thakeow, P.; Phimolsiripol, Y. Optimization of enzymatic production of fructooligosaccharides from longan syrup. J. Appl. Sci. 2012, 12, 1118-1123. [CrossRef]

20. Karboune, S.; Appanah, N.; Khodaei, N.; Tian, F. Enzymatic synthesis of fructooligosaccharides from sucrose by endo-inulinase-catalyzed transfructosylation reaction in biphasic systems. Process Biochem. 2018, 69, 82-91. [CrossRef]

21. Silva, M.F.; Rigo, D.; Mossi, V.; Golunski, S.; Kuhn Gde, O.; Di Luccio, M.; Dallago, R.; de Oliveira, D.; Oliveira, J.V.; Treichel, H. Enzymatic synthesis of fructooligosaccharides by inulinases from Aspergillus niger and Kluyveromyces marxianus NRRL Y-7571 in aqueous-organic medium. Food Chem. 2013, 138, 148-153. [CrossRef]

22. Olwoch, I.P.; Greeff, O.B.W.; Jooné, G.; Steenkamp, V. The effects of the nastural enzyme, Pectinex Ultra SP-L, on human cell cultures and bacterial biofilms in vitro. BMC Microbiol. 2014, 14, 251. [CrossRef]

23. Yun, J.W. Fructooligosaccharides-Occurrence, preparation, and application. Enzyme Microb. Technol. 1996, 19, 107-117. [CrossRef]

24. Goulas, A.K.; Kapasakalidis, P.G.; Sinclair, H.R.; Rastall, R.A.; Grandison, A.S. Purification of oligosaccharides by nanofiltration. J. Membrane Sci. 2002, 209, 321-335. [CrossRef]

25. Nobre, C.; Teixeira, J.A.; Rodrigues, L.R. Fructo-oligosaccharides purification from a fermentative broth using an activated charcoal column. New Biotechnol. 2012, 29, 395-401. [CrossRef] [PubMed]

26. Jadwong, K.; Therdthai, N. Effects of ultrasonicand enzymatic treatment on cooking and eating quality of Sao Hai rice. Food Appl. Biosci. J. 2018, 6, 153-165.

27. Tanongkankit, Y.; Kalantakasuwan, S.; Varit, J.; Narkprasom, K. Ultrasonic-assiated extraction of allicin and its stability during storage. Food Appl. Biosci J. 2019, 7, 17-31.

28. Nadar, S.S.; Rathod, V.K. Ultrasound assisted intensification of enzyme activity and its properties: A mini-review. World J. Microbiol. Biotechnol. 2017, 33, 170. [CrossRef]

29. Wang, D.; Yan, L.; Ma, X.; Wang, W.; Zou, M.; Zhong, J.; Ding, T.; Ye, X.; Liu, D. Ultrasound promotes enzymatic reactions by acting on different targets: Enzymes, substrates and enzymatic reaction systems. Int. J. Biol. Macromol. 2018, 119, 453-461. [CrossRef]

30. Tran, T.T.T.; Nguyen, K.T.; Le, V.V.M. Effects of ultrasonication variables on the activity and properties of alpha amylase preparation. Biotechnol. Prog. 2018, 34, 702-710. [CrossRef]

31. Sun, Y.; Zeng, L.; Xue, Y.; Yang, T.; Cheng, Z.; Sun, P. Effects of power ultrasound on the activity and structure of $\beta$-D-glucosidase with potentially aroma-enhancing capability. Food Sci. Nutr. 2019, 7, 2043-2049. [CrossRef] 
32. Subhedar, P.B.; Gogate, P.R. Enhancing the activity of cellulase enzyme using ultrasonic irradiations. J. Mol. Catal. B Enzym. 2014, 101, 108-114. [CrossRef]

33. O’Donnell, C.P.; Tiwari, B.K.; Bourke, P.; Cullen, P.J. Effect of ultrasonic processing on food enzymes of industrial importance. Trends Food Sci. Technol. 2010, 21, 358-367. [CrossRef]

34. Valero, M.; Recrosio, N.; Saura, D.; Muñoz, N.; Martí, N.; Lizama, V. Effects of ultrasonic treatments in orange juice processing. J. Food Eng. 2007, 80, 509-516. [CrossRef]

35. Miller, G.L. Use of dinitrosalicylic acid reagent for determination of reducing sugar. Anal. Chem. 1959, 31, 426-428. [CrossRef]

36. Endo, H.; Tamura, K.; Fukasawa, T.; Kanegae, M.; Koga, J. Comparison of fructooligosaccharides utilization by Lactobacillus and Bacteroides species. Biosci. Biotechnol. Biochem. 2012, 76, 176-179. [CrossRef]

37. Hu, R. Food Product Design: A Computer-Aided Statistical Approach; Technomic Publishing: Lancaster, PA, USA, 1999; p. 240.

38. Kawee-Ai, A.; Ritthibut, N.; Manassa, A.; Moukamnerd, C.; Laokuldilok, T.; Surawang, S.; Wangtueai, S.; Phimolsiripol, Y.; Regenstein, J.M.; Seesuriyachan, P. Optimization of simultaneously enzymatic fructoand inulo-oligosaccharide production using co-substrates of sucrose and inulin from Jerusalem artichoke. Prep. Biochem. Biotechnol. 2018, 48, 194-201. [CrossRef] [PubMed]

39. Mutanda, T.; Wilhelmi, B.S.; Whiteley, C.G. Biocatalytic conversion of inulin and sucrose into short chain oligosaccharides for potential pharmaceutical applications. Afr. J. Sci. Technol. Innov. Dev. 2015, 7, 371-380. [CrossRef]

40. Kashyap, R.; Palai, T.; Bhattacharya, P.K. Kinetics and model development for enzymatic synthesis of fructooligosaccharides using fructosyltransferase. Bioproc. Biosyst. Eng. 2015, 38, 2417-2426. [CrossRef]

41. Vega-Paulino, R.J.; Zúniga-Hansen, M.E. Potential application of commercial enzyme preparations for industrial production of short-chain fructooligosaccharides. J. Mol. Catal. B Enzym. 2012, 76, 44-51. [CrossRef]

42. Sangeetha, P.T.; Ramesh, M.N.; Prapulla, S.G. Production of fructo-oligosaccharides by fructosyl transferase from Aspergillus oryzae CFR 202 and Aureobasidium pullulans CFR 77. Process Biochem. 2004, 39, 755-760. [CrossRef]

43. Coetzee, G.; van Rensburg, E.; Görgens, J.F. Evaluation of the performance of an engineered $\beta$-fructofuranosidase from Aspergillus fijiensis to produce short-chain fructooligosaccharides from industrial sugar streams. Biocatal. Agric. Biotechnol. 2020, 23, 101484. [CrossRef]

44. Gutteridge, A.; Thornton, J. Conformational change in substrate binding, catalysis and product release: An open and shut case? FEBS Lett. 2004, 567, 67-73. [CrossRef]

45. Park, J.S.; Kenji, K. Application of microbubbles to hydroponics solution promotes lettuce growth. Horttechnology 2009, 19, 212-215. [CrossRef]

46. Northrop, D.B. Effects of high pressure on enzymatic activity. Biochim. Biophys. Acta Protein Struct. Mol. Enzymol. 2002, 1595, 71-79. [CrossRef]

Publisher's Note: MDPI stays neutral with regard to jurisdictional claims in published maps and institutional affiliations.

(C) 2020 by the authors. Licensee MDPI, Basel, Switzerland. This article is an open access article distributed under the terms and conditions of the Creative Commons Attribution (CC BY) license (http://creativecommons.org/licenses/by/4.0/). 